$2013 / 29$

\title{
Suitability of Illite Based Clays of Latvia for Chemical and Thermal Activation
}

\author{
Ingunda Sperberga ${ }^{1}$, Maris Rundans ${ }^{2}$, Gaida Sedmale ${ }^{3}$, Andris Cimmers ${ }^{4}$, Valdis Seglins ${ }^{5}$ \\ ${ }^{1-4}$ Riga Technical University, ${ }^{5}$ University of Latvia
}

\begin{abstract}
Materials has been synthesized in the temperature range from $600-800{ }^{\circ} \mathrm{C}$ from illite based clays of Latvia under activation of $\mathrm{KOH}$ and $\mathrm{NaOH}$ solutions (4-6 M). Compressive strength and apparent porosity were measured. The effect of the concentration of $\mathrm{KOH}$ and $\mathrm{NaOH}$ solutions on the material mechanical properties was investigated by means of infrared spectroscopy (IR). Compressive strength data of the materials showed that via such activation building materials with good quality can be obtained.
\end{abstract}

Keywords: illite based clays, chemical activation, thermal activation, compressive strength.

\section{INTRODUCTION}

Alkaline activation is a chemical process in which a powder material of an aluminosilicate nature is mixed with an alkaline activator to produce a paste that is able to set and harden in a short time [1,2]. Inorganic polymers (termed also geopolymers), introduced by Davidovits in the early 1970s, are a class of largely X-ray amorphous alumosilicate materials, generally synthesized at ambient or slightly elevated temperature by reaction of a solid aluminosilicate powder with a concentrated alkali metal silicate or hydroxide solution [3]. The reaction process of this system is characterized by dissolution of aluminosilicate oxides and followed by the polymerization reaction of those dissolved species, in the presence of alkali ions for charge balancing in framework cavities nearby $\mathrm{AlO}_{4}$ constituents. Geopolymeric materials possess excellent mechanical properties, including fire and acid resistance [3,4]. Geopolymer matrices also have been proven to stabilize, solidify and encapsulate metallic and radioactive wastes and industrial wastewater [5]. The mentioned properties depend on many factors including the type of starting materials, the mineralogical and chemical composition in the aluminosilicate sources. Aluminosilicates are the most abundant compounds in the earth's crust. There exist a large number of starting materials rich in alumina and silica with the potential for producing of inorganic polymers $[6,7]$. Among these materials the most common geopolymeric reactants in the past decades are kaolinite and metakaolinite [8-10].

The search for alternative low cost and easily available materials have lead among another materials to illite-based clays. The clay deposits traditional subdivision in Latvia is based on geological age with specific attention to beds with industrial importance - Devonian and Quaternary deposits. From geological point of view - Latvia is rich in clay resources to be used for material production currently and at least for centuries [11].
The aim of this work is the study of alkaline dissolution and geopolymerisation of natural Quaternary and Devonian illite based clays of Latvia for building material production.

\section{MATERIALS AND METHODS}

Quaternary (Q) (Prometejs deposit) and Devonian (D) (Pavari deposit) illite-based clays of Latvia used for geopolymer synthesis were characterized by means of chemical analysis, X-ray diffraction (model Rigaku, Japan, with $\mathrm{CuK}_{\alpha}$ radiation at a scanning interval from $2 \theta=10-60^{\circ}$ and speed $4 \% / \mathrm{min}$.) and differential thermal analysis (SETERAM SETSYS Evolution, 1750, heating rate $10 \%$ min.).

In order to investigate the effect of the activators $(\mathrm{KOH}$ and $\mathrm{NaOH})$ on the properties of the material, two series $(\mathrm{Q}$ and D) were tested. The potassium and sodium hydroxide solutions were obtained by dissolving dried pellets of $99 \%$ purity in distilled water. Thus the activators were added to the clay powders and mechanically mixed. Afterwards cylindric samples $(\mathrm{h}=25 \mathrm{~mm}, \mathrm{~d}=16 \mathrm{~mm})$ were made in plastic way with $25-30 \%$ of average moisture content. Samples were allowed to mature at room temperature for 7 days to increase their mechanical strength. Afterwards samples were thermally activated at 600,700 and $800{ }^{\circ} \mathrm{C}$ temperature. Final samples were used for the mechanical strength and apparent porosity measurements.

Compressive strength was determined by means of the "Compression Test Plant ToniNorm" Toni-Technic by Zwick $(300 \mathrm{kN})$.

Fourier transform infrared spectroscopy was carried out on powders of hardened materials using "21 Prestige, Shimadzu Corp" FTIR spectrophotometer in transmittance mode. FTIR spectra were gathered between 400 and $1600 \mathrm{~cm}^{-1}$.

\section{RESULTS AND DISCUSSION}

Table 1 shows differences in chemical composition between the studied clays. Content of $\mathrm{CaO}$ is higher for clay $\mathrm{Q}$ than that of $\mathrm{D}$ clay. The presence of calcium provides extra nucleation sites for precipitation of dissolved species, which may be used to tailor setting times and material properties [12]. In order to achieve high strength and durability, Davidovits [13] recommended the use of certain ratios $\mathrm{SiO}_{2} / \mathrm{Al}_{2} \mathrm{O}_{3}$ from 2.5-4.5. In the case of $\mathrm{Q}$ clay $\mathrm{SiO}_{2} / \mathrm{Al}_{2} \mathrm{O}_{3}$ ratio is 2.7 and in the case of $\mathrm{D}$ clay - 3.8. The $\mathrm{Al}_{2} \mathrm{O}_{3}$ and $\mathrm{CaO}$ are regarded as more significant elements than the others, because $\mathrm{AlO}_{4}^{-}$and silicate oligomers combine to form geopolymers [14]. The $\mathrm{CaO}$ content of source material appears to strengthen the geopolymer by forming amorphously structured Ca-Al-Si gel during geopolymerisation [15]. 
TABLE 1

CHEMICAL COMPOSITION OF THE STUDIED CLAYS, WEIGHT \%

\begin{tabular}{|c|c|c|c|c|c|c|c|c|c|}
\hline & $\mathrm{SiO}_{2}$ & $\mathrm{Al}_{2} \mathrm{O}_{3}$ & $\mathrm{Fe}_{2} \mathrm{O}_{3}$ & $\mathrm{TiO}_{2}$ & $\mathrm{CaO}$ & $\mathrm{MgO}$ & $\mathrm{Na}_{2} \mathrm{O}$ & $\mathrm{K}_{2} \mathrm{O}$ & LOI* \\
\hline $\mathrm{Q}$ & 46.0 & 17.1 & 6.6 & 0.6 & 6.0 & 3.9 & 0.2 & 3.9 & 15.7 \\
\hline $\mathrm{D}$ & 63.2 & 16.7 & 7.6 & 0.8 & 0.8 & 2.1 & 0.1 & 3.5 & 5.2 \\
\hline
\end{tabular}

X-ray patterns of both studied clays presented in Fig.1. contain clearly visible reflections of quartz and illite. Illite is an alumosilicate which can react in alkaline conditions. Its presence in both clays is therefore a significant feature which can affect geopolymerisation [16]. The reflections of kaolinite, calcite and dolomite are observed only for Q clay. Previous studies have shown that the addition of moderate amount of calcium-containing material can have a significant effect on the structure and properties of final material [17-19]. Besides both clays contain feldspar - microcline, but D clay - hematite as well.

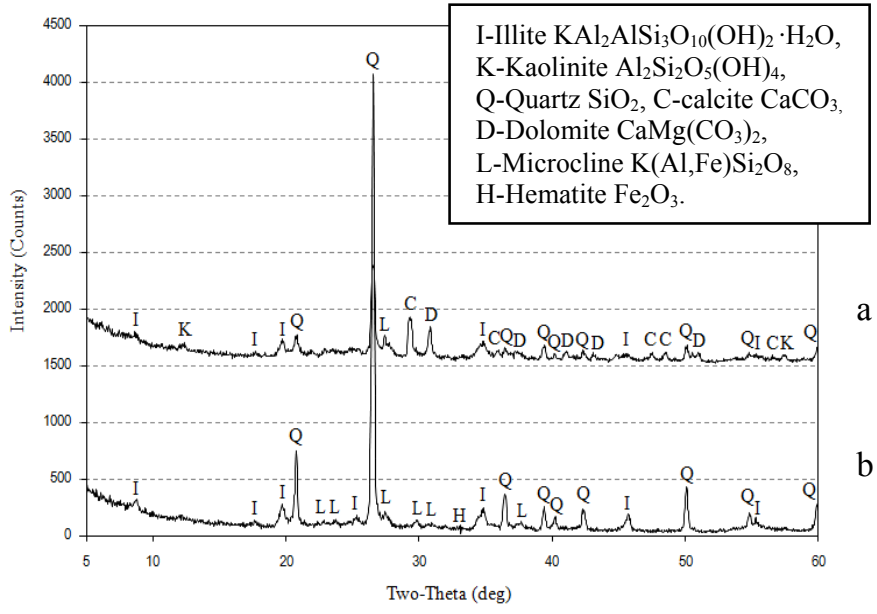

Fig. 1. XRD patterns of noncalcinated clays: $a-Q$ clay, $b-D$ clay.

Thermal analysis presented in Fig.2 shows that there are differences not only between temperatures of endothermic and exothermic effects of the studied clays, but also in character of both DTA curves giving evidence on the used clay difference.

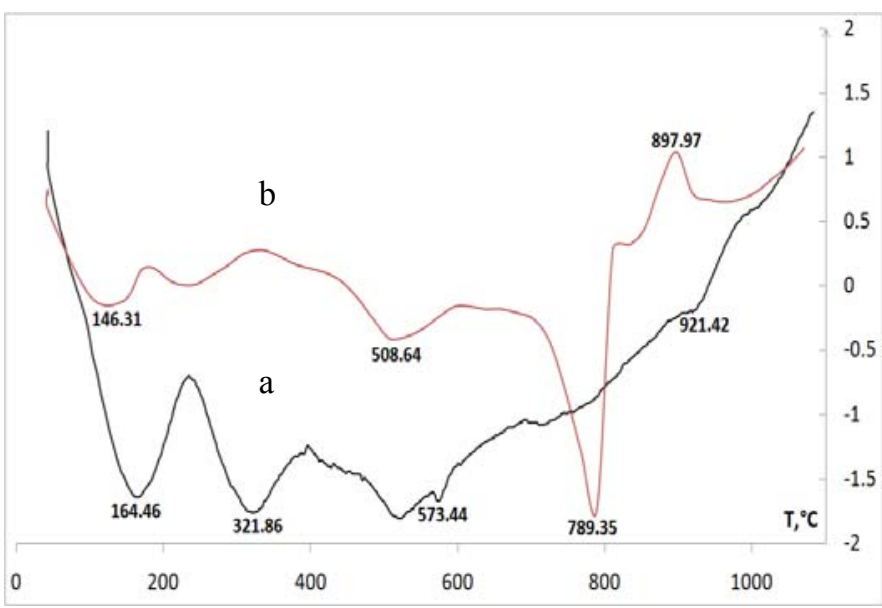

Fig. 2. Thermal analysis of : $a-D$ clay; $b-Q$ clay.

It is known that the type of cation involved in the activation process could affect the development of the structure. In general it can be affirmed that the $\mathrm{OH}^{-}$ion acts as a reaction catalyst, but the alkaline metal cation acts as a structure forming element, balancing the negative framework charge carried by tetrahedral aluminium. $\mathrm{NaOH}$ or $\mathrm{KOH}$ are commonly used as alkaline activators.

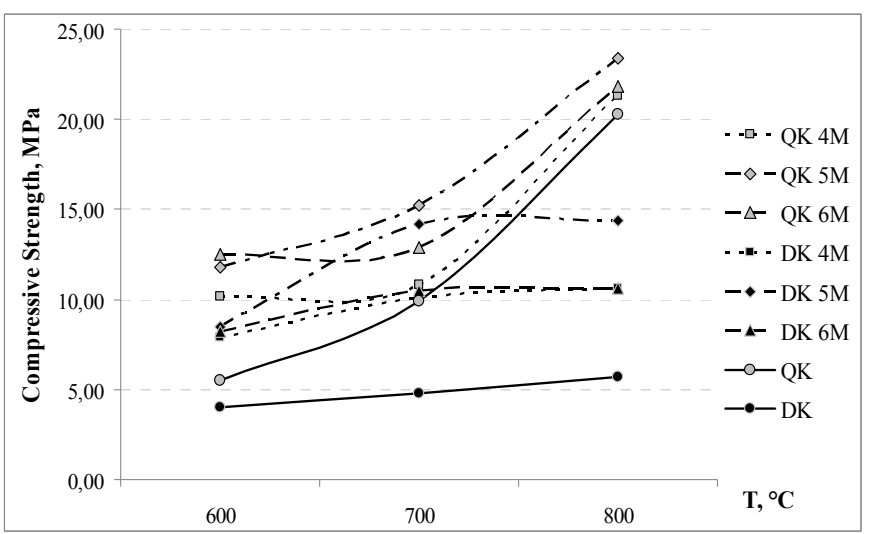

Fig. 3. Compressive strength evolution vs. $\mathrm{KOH}$ concentration at different firing temperatures.

Fig. 3 presents the role of $\mathrm{KOH}$ as a chemical activator on the compressive strength of final materials obtained from both studied clays and thermally treated at different temperatures. $\mathrm{KOH}$ solution with higher used concentration $(6 \mathrm{M} \mathrm{KOH})$ did not promote the strength enhancement for both clays. The higher compressive strength $\left(24 \mathrm{MPa}\right.$ at $\left.800^{\circ} \mathrm{C}\right)$ showed $\mathrm{Q}$ clay activated with $5 \mathrm{M} \mathrm{KOH}$ solution. By activation with $4 \mathrm{M}$ and $6 \mathrm{M}$ compressive strength of materials obtained from $\mathrm{Q}$ clay was analogous $(22 \mathrm{MPa})$. Obviously a higher concentration of $\mathrm{KOH}$ solution facilitates the dissociation of different silicate and aluminate species, thus promoting further polymerization resulting in higher compressive strength. However, if a very high alkaline environment is used, the connectivity of silicate anions may be reduced resulting thus in poor polymerization and lower compressive strength. Compressive strength increases with an increasing of treatment temperature in all cases.

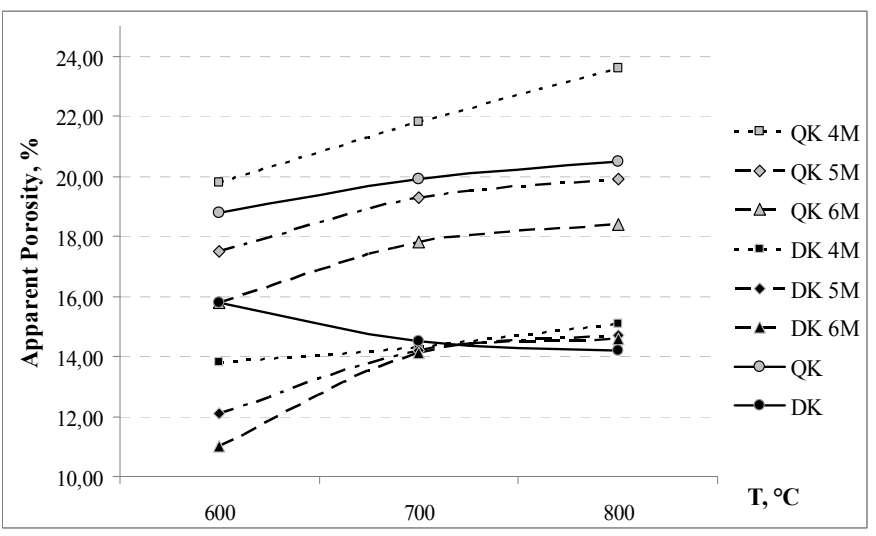

Fig. 4. Porosity evolution vs. $\mathrm{KOH}$ concentration at different firing temperatures.

Contrary to Q clay compressive strength is lower when D clay is treated with $\mathrm{KOH}$ solution reaching the best values $(14 \mathrm{MPa})$ of the compressive strength already at $700^{\circ} \mathrm{C}$. 
Compressive strength in the case of $\mathrm{D}$ clay at higher temperatures increases just slightly.

Porosity evolution with temperature increasing depending on $\mathrm{KOH}$ solution alkalinity is shown in Fig. 4. Porosity increases along with temperature for materials obtained both from Q clay and D clay. Higher porosity value (23.7\%) shows material obtained from Q clay and activated with $4 \mathrm{M} \mathrm{KOH}$ solution. Using $5 \mathrm{M}$ and $6 \mathrm{M} \mathrm{KOH}$ solution for chemical activation porosity is lower than that of nonactivated $\mathrm{Q}$ clay (QK 0M) at the same temperatures. Porosity of materials from $\mathrm{D}$ clay activated with $\mathrm{KOH}$ solution gave lower results at all used temperatures. Difference among porosities of variously obtained materials from D clay is very small. Taking into account results on compressive strength the best values could reach using $5 \mathrm{M} \mathrm{KOH}$ solution in this case.

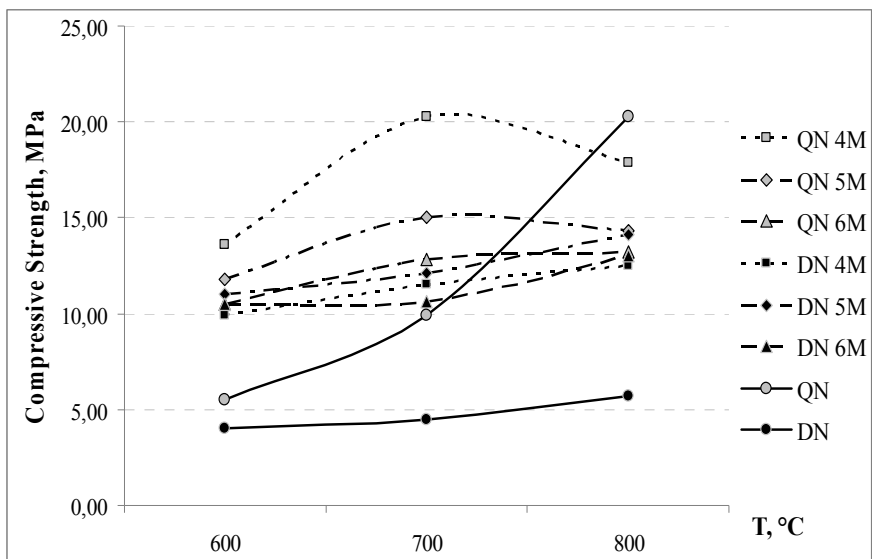

Fig. 5. Compressive strength evolution vs. $\mathrm{NaOH}$ concentration at different firing temperatures.

The results presented in Fig. 5 shows the effect of $\mathrm{NaOH}$ solution on the compressive strength of materials obtained from both used clays. The strength increased along with the decrease of the concentration of $\mathrm{NaOH}$ for $\mathrm{Q}$ clay. In other words, the lower $\mathrm{Na}_{2} \mathrm{O} / \mathrm{Al}_{2} \mathrm{O}_{3}$ and $\mathrm{Na}_{2} \mathrm{O} / \mathrm{SiO}_{2}$ ratios promoted the strength improvement than higher ones in the case of $\mathrm{Q}$ clay. Obviously using higher than $4 \mathrm{M} \mathrm{NaOH}$ concentration for chemical activation, excess hydroxide ion concentration caused alumosilicate gel precipitation at the very early stages, resulting in lower compressive strength. The highest compressive strength $(20.2 \mathrm{MPa})$ showed material activated with $4 \mathrm{M} \mathrm{NaOH}$ and thermally treated at $700{ }^{\circ} \mathrm{C}$, and it is two times higher than that of chemically nontreated clay $(10 \mathrm{MPa})$ at the same thermal treatment temperature. The chemical treatment of $\mathrm{D}$ clay with different $\mathrm{NaOH}$ concentrations gave quite similar results reaching higher compressive strength (1314.5 MPa) at higher temperature $\left(800{ }^{\circ} \mathrm{C}\right)$ than that was in the case of $\mathrm{Q}$ clay.

All obtained materials (both from Q clay and D clay) thermally treated at $700{ }^{\circ} \mathrm{C}$ temperature have shown a higher porosity (Figure 6). The Above and below mentioned temperature porosity decreases reaching nearly equal values. In addition to that materials from $\mathrm{Q}$ clay in comparison with $\mathrm{D}$ clay in all used temperature range show higher porosity. The porosity has increased along with an increase of $\mathrm{NaOH}$ concentration for $\mathrm{Q}$ clay. The role of $\mathrm{NaOH}$ concentration on the porosity of materials obtained from $\mathrm{D}$ clay is not essential - with the increasing of alkalinity the porosity of materials changes just slightly.

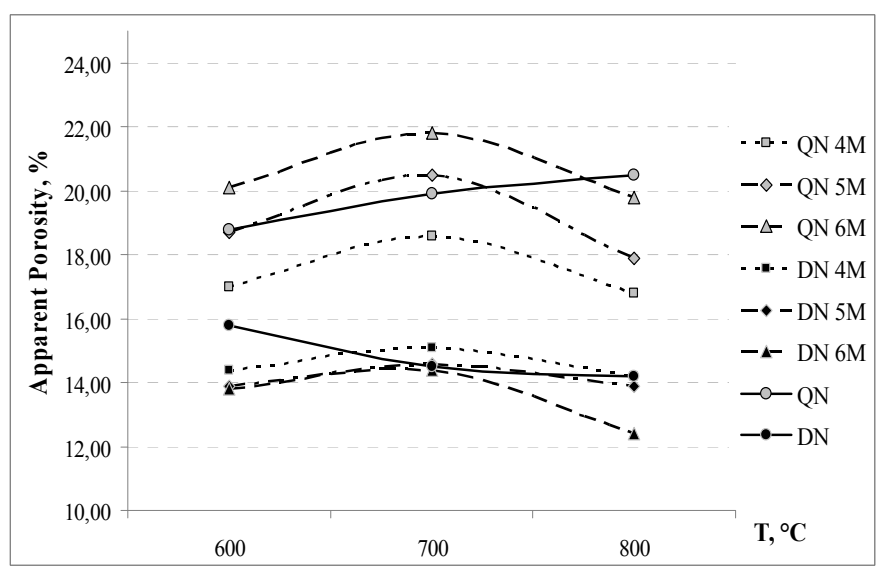

Fig. 6. Porosity evolution vs. $\mathrm{NaOH}$ concentration at different firing temperatures.

FTIR analysis shows an increased sensitivity for structures of short-range structural order and is considered as an appropriate technique for studying the structural evolution of amorphous alumosilicates exhibiting high heterogeneity [20]. Infrared absorption bands enable identification of specific molecular components and structures.

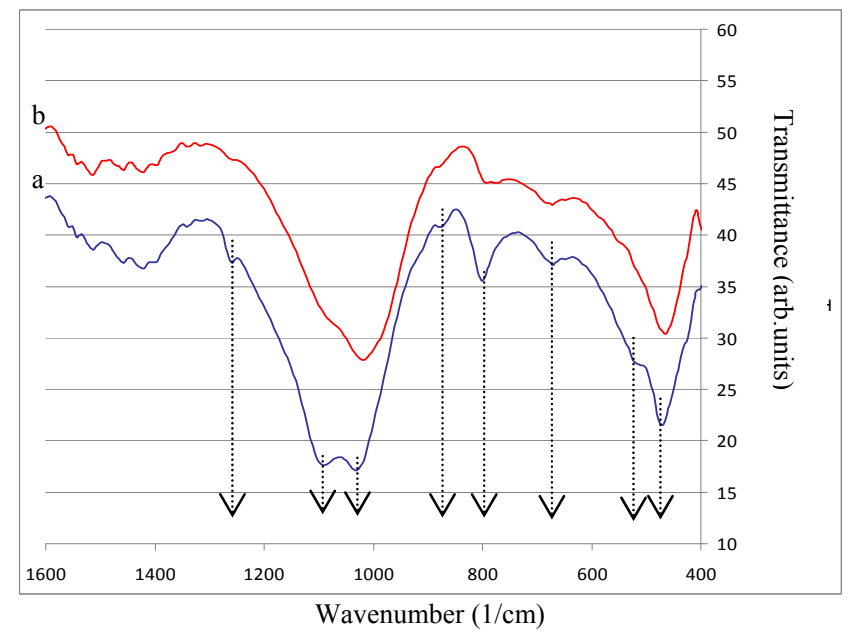

Fig. 7. FTIR spectra of materials from Q clay and thermally treated at $700{ }^{\circ} \mathrm{C}$ : $\mathrm{a}$ - activated with $4 \mathrm{M} \mathrm{KOH}$ solution; $\mathrm{b}$ - activated with $4 \mathrm{M} \mathrm{NaOH}$ solution.

The difference in absorption frequencies between differently activated $\mathrm{Q}$ clay predicts transformations taking place during material synthesis. The bands at $470 \mathrm{~cm}^{-1}$ seen for both specimens are due to bending vibrations of $\mathrm{Si}-\mathrm{O}-\mathrm{Si}$ and $\mathrm{O}-\mathrm{Si}-\mathrm{O}$ bonds indicating that quartz is almost chemically inert in the strong alkaline activating solutions [21, 22]. The small band seen at $\sim 530 \mathrm{~cm}^{-1}$ only for material obtained by activating with $\mathrm{KOH}$ solution is mainly due to the symmetric stretching vibrations of Si-O-Si and Al-O-Si [23], which are referred to the formation of amorphous to semi-crystalline alumosilicate materials. The bands at $680 \mathrm{~cm}^{-1}$ represent the Si-O symmetrically stretching showing that 6-coordinated Al changed into 4-coordinated one, and participates in the formation of framework structure [10]. The very small band 
seen at $870 \mathrm{~cm}^{-1}$ corresponds to dissolved silicate and/or alumosilicate species and indicates that dissolution of raw materials takes place [24]. Characteristic band at $1033 \mathrm{~cm}^{-1}$ has been assigned to asymmetric stretching of Al-O and $\mathrm{Si}-\mathrm{O}$ bonds originating from within individual tetrahedra. All bands at around $1088 \mathrm{~cm}^{-1}$ are a major fingerprint of the inorganic polymer matrix and define the extent of polysialation or aluminium incorporation; they are also due to asymmetric stretching of $\mathrm{Al}-\mathrm{O}$ and $\mathrm{Si}-\mathrm{O}$ bonds originating from within individual tetrahedra [21]. The very small band seen at $1270 \mathrm{~cm}^{-1}$ may be due to $\mathrm{Si}-\mathrm{O}-\mathrm{Si}$ or $\mathrm{Al}-\mathrm{O}-\mathrm{Si}$ asymmetric stretching vibration as a result of $\mathrm{SiO}_{4}$ and $\mathrm{AlO}_{4}$ reorganisation that takes place during synthesis [24].

Alkali metal cations play a catalytic role and could contribute to strong structure formation. It was shown that both clays demonstrated higher compressive strengths after activation in $\mathrm{KOH}$ than in $\mathrm{NaOH}$. $\mathrm{KOH}$ provides more inorganic polymer precursors compared to $\mathrm{NaOH}$ since the larger $\mathrm{K}^{+}$favours the formation of larger silicate oligomers with which $\mathrm{Al}(\mathrm{OH})_{4}{ }^{-}$prefers to bind, thus higher compressive strength is acquired.

\section{CONCLUSIONS}

The main factors affecting the synthesis of materials from illite based clays of Latvia include mineralogy of the used clays, alkali concentration and activator as well as thermal treatment temperature. The results clearly showed the influence of the clay types and another parameter could be the $\mathrm{Si} / \mathrm{Al}$ ratio, which influences the sintering process of materials and eventually - compressive strength. Inorganic polymers obtained from Quaternary clay of Latvia, where $\mathrm{SiO}_{2} / \mathrm{Al}_{2} \mathrm{O}_{3}$ ratio is 2.7 , acquire the best compressive strength of $24 \mathrm{MPa}$ when $5 \mathrm{M} \mathrm{KOH}$ is used.

The present study showed that illite based Quaternary clays could be as a source material for the synthesis of inorganic polymers.

\section{REFERENCES}

[1] Duxson, P., Fernandez-Jimenez, A., Provis, J. L., et.al. Geopolymer technology: the current state of the art. Journal of Materials Science, 2007, 42, p. 2917-2933. http://dx.doi.org/10.1007/s10853-006-0637-Z

[2] Steins, P., Poulesquen, A., Diat, O., Frizon, F. Structural evolution during geopolymerization from an early age to consolidated material. Langmuir, 2012, 28, p. 8502-8510. http://dx.doi.org/10.1021/la300868v

[3] Davidovits, J. Geopolymers: Inorganic polymeric new materials. Journal of Thermal Analysis, 1991, 37, p. 1633-1656. http://dx.doi.org/10.1007/BF01912193

[4] Davidovits, J. Geopolymer chemistry \& applications. 2nd edition, chapters 15-16. Saint-Quentin: Institute Géopolymère, 2008. p. 333365 .

[5] Izguierdo, M., Querol, X., Phillipart, C., et.al. The role of open and closed curing conditions on the leaching properties of fly ash-slag-based geopolymers. Journal of Hazardous Materials, 2010, 176, p. 623-628. http://dx.doi.org/10.1016/j.jhazmat.2009.11.075

[6] Xu, H., Van Deventer, J. S. J. The geopolymerisation of alumosilicate minerals. International Journal of Mineral Processing, 2000, 59, 3, p. 247-266. http://dx.doi.org/10.1016/S0301-7516(99)00074-5

[7] Xu, H., Van Deventer, J. S. J. Geopolymerisation of multiple minerals. Minerals Engineering, 2002, 15, p. 1131-1139. http://dx.doi.org/10.1016/S0892-6875(02)00255-8 .
[8] Kuenzel, C., Vandeperre, L. J., Donatello, S., et.al. Ambient temperature drying shrinkage and cracking in metakaolin-based geopolymers. Journal of American Ceramic Society, 2012, 95, p. 32703277. http://dx.doi.org/10.1111/j.1551-2916.2012.05380.x

[9] Elimbi, A., Tchakoute Kouamo, H., Njopwouo, D. Effects of calcination temperature of kaolinite clays on the properties of geopolymer cements. Construction and Building Materials, 2011, 25, p. 2805-2812. http://dx.doi.org/10.1016/j.conbuildmat.2010.12.055

[10] Zhang, Y., Wei, S., Zongjin, L. Composition design and microstructural characterization of calcined kaolin-based geopolymer cement. Applied Clay Science, 2012, 47, p. 271-275.

[11] Seglins, V. Applied geological studies of silicate raw materials and new perspectives in Latvia. Scientific Proceedings of Riga Technical University, Material Science and Applied Chemistry, Riga, Latvia, 2008, 1, 17, p. 62-67.

[12] Van Deventer, J. S. J., Provis, J. L, Duxson, P., Lukey, G. C. Reaction mechanisms in the geopolymeric conversation in inorganic waste to useful products. Journal of Hazardous Materials, 2007, 139, p. 506-513. http://dx.doi.org/10.1016/j.jhazmat.2006.02.044

[13] Davidovits, J. Chemistry of geopolymeric systems. In:Proceedings of 99 Geopolymer Conference, France, 1999, vol. 1, p. 9-40.

[14] Xu, H., Van Deventer, J. S. J. The geopolymerisation of alumosilicate minerals. International Journal of Mineral Processing, 2000, 59, 3, p. 247-266. http://dx.doi.org/10.1016/S0301-7516(99)00074-5

[15] Yip, C. K., Lukey, G. C., Provis, J. L., Van Deventer, J. S. J. Effect of calcium silicate sources on geopolymerisation. Cement and Concrete Research, 2008, 38, 4, p. 554-564. http://dx.doi.org/10.1016/j.cemconres.2007.11.001

[16] Zibouche, F., Kerdjoudj, H., d'Espinose de Lacaillerie, J. B., Van Damme, H. Geopolymers from algerian metakaolin. Influence of secondary minerals. Applied Clay Science, 2009, 43, 3-4, p. 453-458.

[17] Alonso, S., Palomo, A. Calorimetric study of alkaline activation of calcium hydroxide-metakaolin solid mixtures. Cement and Concrete Research, 2005, 31, 1, p. 25-30. http://dx.doi.org/10.1016/S0008$\underline{8846(00) 00435-X}$

[18] Dombrowski, K., Buchwald, A., Weil, M. The influence of calcium content on the structure and thermal performance of fly ash based geopolymers. Journal of Materials Science, 2007, 42, 9, 3033-3043. http://dx.doi.org/10.1007/s10853-006-0532-7

[19] Yip, C. K., Lukey, G. C., Provis, J. L., Van Deventer, J. S. J. Effect of calcium silicate sources on geopolymerisation. Cement and Concrete Research, 2008, $38, \quad 4, \quad 554-564$. http://dx.doi.org/10.1016/j.cemconres.2007.11.001

[20] Lee, W. K. W., Van Deventer, J. S. J. The effects of inorganic salt contamination on the strength and durability of geopolymers. Colloids and Surfaces A: Physicochemical and Engineering Aspects, 2002, vol. 211, Issues 2-3, p. 115-126.

[21] Van Jaarsveld, J. G. S., Van Deventer, J. S. J., Lukey, G. C. The effect of composition and temperature on the properties of fly ash- and kaolinite-based geopolymers. Chemical Engineering Journal, 2002, 89, 1-3, 63-73. http://dx.doi.org/10.1016/S1385-8947(02)00025-6

[22] Lee, W. K. W., Van Deventer, J. S. J. Structural reorganization of Class F fly ash in alkaline silicate solutions. Colloids and Surfaces A: Physicochemical and Engineering Aspects, 2002, vol. 211, Issues 2-3, p. 49-66.

[23] Bakharev, T. Geopolymeric materials prepared using Class F fly ash and elevated temperature curing. Cement and Concrete Research, 2005 , 35, p. 1224-1232. http://dx.doi.org/10.1016/j.cemconres.2004.06.031

[24] Rees, C. A., Provis, J. L, Lukey, G. C. Van Deventer, J. S. J. Attenuated total reflectance fourier transform infrared analysis of fly ash geopolymer gel aging. Langmuir, 2007, 23, p. 8170-8179. http://dx.doi.org/10.1021/la700713g

Ingunda Sperberga, Dr.sc.ing. (1998), Assoc.Prof./Lead.Researcher at Riga Technical University, Faculty of Materials Science and Applied Chemistry, Institute of Silicate Materials. She is the author of more than 90 publications, including 6 monographs and textbooks concerning crystallography, mineralogy, mineral raw materials of Latvia and physical chemistry of silicates.

Address: Azenes Str. 14/24, LV 1048, Riga, Latvia

Phone: + 371 67089266, Fax: + 37167615765

E-mail: sperberga@ktf.rtu.lv 
Maris Rundans is a Doctoral Student at Riga Technical University, Faculty of Materials Science and Applied Chemistry. He is the author of 10 scientific papers in the field of silicate materials. Fields of interest include the use of natural materials for development of ceramic products.

Address: Azenes Str. 14/24, LV 1048, Riga, Latvia

Phone: + 371 67089266, Fax: + 37167615765

E-mail: marisr87@inbox.lv

Gaida Sedmale, Dr.habil.chem, Assoc.Prof./Leading Researcher at Riga Technical University, Faculty of Materials Science and Applied Chemistry, Institute of Silicate Materials. She is the suthor of more than 200 scientific publications in the branch of glass and ceramic chemistry and technology. Main outputs of glassy and ceramic materials are protected by more than 50 patents of Latvia and Russia. During 20 years her scientific interests have been connected with new high-temperature and traditional ceramic materials She delivers the lecture course "Chemistry and Technology of Fine Ceramics" for bachelor and master of science degree students.

Address: Azenes Str. 14/24, LV 1048, Riga, Latvia

Phone: + 371 67089257, Fax: + 37167615765

E-mail:gsedmale@ktf.rtu.lv
Andris Cimmers, Dr.sc.ing. (1987), Lead.Researcher at Riga Technical University, Faculty of Materials Science and Applied Chemistry, Institute of Silicate Materials. He is the author of more than 60 publications. The main outputs are protected by 15 patents of Latvia and Russia.

Address: Azenes Str. 14/24, LV 1048, Riga, Latvia

Phone: + 371 67615560, Fax: + 37167615765

E-mail: cimmers@ktf.rtu.lv

Valdis Seglins. Dr geol., Professor at the University of Latvia, Faculty of Geography and Earth Sciences, Department of Geology. He is the author of up to 300 scientific publications in the area of Earth Sciences.

Address: Raina bulv. 19, LV1050, Riga, Latvia.

Phone +37167331, Fax: +371 67332704 .

E-mail: valdis.seglins@lu.lv

Ingunda Šperberga, Māris Rundāns, Gaida Sedmale, Andris Cimmers, Valdis Segliṇš. Latvijas illīta mālu piemērotība ḳīmiskai un termiskai aktivācijai.

Rakstā aplūkota Latvijas kvartāra un devona illītu saturošu mālu kīmiska aktivēšana ar dažādas koncentrācijas KOH un NaOH šķīdumiem un to piemērotība būvniecības keramikas izstrādei zemākās temperatūrās, salīdzinot ar tradicionālu keramikas materiālu ieguvi. Illīts ir alumosilikāts, kas var reaǵèt sārmainos apstākḷos un tā klātbūtnei abos mālos ir svarīga loma geopolimerizācijas procesā. Kā galvenais rādītājs geopolimerizācijas procesa sekmīgai norisei izvēlēta iegūto materiālu spiedes stiprība, kas pieaug līdz ar temperatūras paaugstināšanos karbonātus saturošos kvartāra mālos, ja kā aktivators tiek izmantots KOH šķ̄īums. Bezkarbonātu (devona) mālos augstākā spiedes stiprība tiek sasniegta $700^{\circ} \mathrm{C}$, kas tālākā apdedzināšanas procesā vairs nepieaug. Aktivācijas procesā ar $\mathrm{NaOH}$ šķ̄îumu tiek iegūti materiāli, kuru spiedes stiprības rādīiāji ir zemāki (kvartāra mālu gadījumā) vai līdzịgi (devona mālu gadījumā) ar rādītājiem, kas iegūti izmantojot KOH škīidumu. Tomēr salīdzinot ar ķīmiski neaktivēta māla spiedes stiprību (10 MPa), šajā gadījumā iegūts materiāls, kura spiedes stiprība ir divas reizes lielāka (20.2 MPa), ja kā ķīmiskās aktivācijas šķ̄idums tiek izmantots $4 \mathrm{M} \mathrm{NaOH}$ un apdedzināšanas temperatūra ir $700^{\circ} \mathrm{C}$. Pētījumi parādīja, ka tā vai cita sārmu hidroksīda izmantošana ġeopolimerizācijas procesā deva dažādus rezultātus, kuri atkarīgi no vairākiem faktoriem, no kuriem svarīgākais ir izmantotā izejviela - māls. Sakarā ar katjonu katalītisko lomu, svarīgs ir katjons, kas ietilpst hidroksīdā (NaOH vai $\mathrm{KOH})$, ar kuru māls tiek apstrādāts. Iegūto geopolimērmateriālu var uzskatīt kā tradicionālo būvmateriālu aizstājēju. Tas iegūts zemākā temperatūrā, nezaudējot spiedes stiprību, salīdzinot ar tradicionāliem būvmateriāliem.

Ингунда Шперберга, Марис Рунданс, Гайда Седмале, Андрис Циммерс, Валдис Сеглиньш. Пригодность иллитовых глин Латвии для химической и термической активации.

Исследованны процессы по использованию четвертичных (карбонатсодержащих) и девонских (малокарбонатных) иллитовых глин Латвии для химической активации в $\mathrm{KOH}$ и $\mathrm{NaOH}$ растворах различной концентрации для применения при разработке керамических строительных материалов. При помощи инфракрасной спектроскопии установлено, что при химической обработке четвертичной и девонской глины с растворами $\mathrm{KOH}$ и $\mathrm{NaOH}$ происходит изменение структуры иллитов в части спектра, которая указывает на изменение положения связей $\mathrm{Si}-\mathrm{O}-\mathrm{Si}$ и $\mathrm{Al}-\mathrm{O}-\mathrm{Si}$, которые свидельствуют о формировании аморфных до полукристаллических алюмосиликатных материалов. Наблюдаются также изменеия относительно образования новой связи $\mathrm{Al}-\mathrm{O}$, в группе $\mathrm{AlO}$, где ион $\mathrm{Al}$ является 4-х координоионным. Эти стуктурные изменения позволяют снизить температуру обжига керамики на $250-300^{0} \mathrm{C}$ по сравнению с традиционно применяемой в интервале $950-1000^{\circ} \mathrm{C}$ и обеспечивают прочность на сжатие в пределах $15-25$ МРа. Использование того или иного гидроксида щелочного металла в процессе геополимеризации зависит от многих факторов, из которых наиболее важным является используемое сырье - Четвертичная (карбонатсодержащая) или Девонская (малокарбонатная) глина. Изза каталитической роли катионов важным является катион в качестве базового материала, а также катион, добавляемый в качестве гидроксида щелочного металла. В связи с тем получена различная прочность на сжатие при замене активатора, концентрации активатора и температуре термической обработки. Геополимерные материалы можно рассматривать как заменители традиционных строительных материалов. 